\title{
Climate change and lung health: the challenge for a new president
}

\author{
Nicholas S Hopkinson, ${ }^{1}$ Nicholas Hart, ${ }^{2}$ Gisli Jenkins, ${ }^{3}$ \\ Naftali Kaminski, ${ }^{4}$ Margaret Rosenfeld, ${ }^{5}$ Alan Smyth, ${ }^{6}$ Alex Wilkinson ${ }^{7}$
}

This is a story from recent history that we believe incoming President Trump urgently needs to hear. In 1985, a huge and growing hole in the planet's ozone layer was identified. Ozone in the stratosphere blocks some of the sun's ultraviolet radiation from reaching the Earth's surface, thus protecting its biosphere (which includes humans) from DNA damage that would otherwise occur. The hole was caused by the action of chlorofluorocarbons (CFCs) used in refrigeration and as aerosol propellants. ${ }^{1}$ Margaret Thatcher is admired by many on both sides of the Atlantic, including President Trump ${ }^{2}$ as a strong politician, a person with clear beliefs on which she acted; the 'Iron Lady' as Donald Trump has described her on Twitter. A scientist by background, Thatcher appreciated the magnitude of the threat immediately, throwing her weight behind international efforts to address this. Working with Ronald Reagan, within 2 years the 1987 Montreal Protocol was signed to phase out the production and use of CFCs. Despite this, because CFCs persist in the atmosphere for more than a century, the ozone layer will not recover completely until 2060. A failure of leadership at that time would have been catastrophic. CFCs are also powerful greenhouse gases and without the Montreal agreement the world would already be $3^{\circ} \mathrm{C}$ warmer. Combined with the increased radiation levels, inexorable atmospheric chemistry would have left

${ }^{1}$ NIHR Respiratory Disease, Biomedical Research Unit at the Royal Brompton and Harefield NHS Foundation Trust and Imperial College London, London, UK; ${ }^{2}$ Lane Fox Respiratory Service, St Thomas' Hospital Guy's \& St Thomas' NHS Foundation Trust London, London, UK; ${ }^{3}$ Centre for Respiratory Research, University of Nottingham, Nottingham, UK; ${ }^{4}$ Pulmonary, Critical Care and Sleep Medicine, Yale School of Medicine, New Haven, Connecticut, USA; ${ }^{5}$ University of Washington School of Medicine Seattle Children's Hospital, Seattle, Washington, USA; ${ }^{6}$ School of Medicine, University of Nottingham, Nottingham, UK; ${ }^{7}$ Department of Respiratory Medicine, East and North Hertfordshire NHS Trust, Stevenage, Hertfordshire, UK

Correspondence to Corresponding author $\mathrm{Dr}$ Nicholas S Hopkinson, NIHR Respiratory Biomedical Research Unit, Royal Brompton and Harefield NHS Foundation Trust and Imperial College, The Royal Brompton Hospital, Fulham Road, London SW3 6NP, UK; n.hopkinson@ic.ac.uk much of the planet uninhabitable by the middle of this century. ${ }^{3}$ End of story.

A similar challenge faces us now. The evidence that climate change is happening, driven by human activities which increase atmospheric greenhouse gases, is overwhelming. ${ }^{4}$ Increased temperatures and disruption of ecosystems by climate change impact directly on health and on lung health in particular. ${ }^{4-8}$ Vector-borne diseases may worsen (as vector distribution, breeding and feeding patterns change), crop failure (from flooding, heat waves and extreme weather events) will drive starvation and cases of bacterial diarrhoea and exposure to toxic algal blooms will increase. ${ }^{4}$ Climate change can increase exposure to pollen and mould allergens. Raised temperatures increase concentrations of ground-level ozone and particulates. This impacts both the development and the severity of asthma, rhinosinusitis, COPD and respiratory tract infections. ${ }^{6}$ Smoke from forest fires related to heat waves impacts lung health.

The effects of climate change are more likely to be felt by those with pre-existing cardiopulmonary disease and by disadvantaged individuals. For example, heat wave-related mortality has been found to be higher among those with chronic respiratory disease, even among hospitalised patients. ${ }^{9}$ These disruptions are also a cause of poverty, conflict and mass population displacement, ${ }^{10}$ increasing individuals' susceptibility to illness and reducing their ability to access healthcare. Extreme weather events are increasing, with devastating consequences. This represents a significant global injustice, as those who experience the greatest impact of climate change are in general those least responsible for it. No society is immune however.

It is clear that the cost of limiting climate change now is far less than the cost of addressing the consequences in the future. ${ }^{11} 12$ This is particularly the case if we can avoid tipping points related to arctic ice melting and the melting of permafrost that releases methane, accelerating the greenhouse effect. Economically, climate change is an opportunity as well as a threat-business needs a clear signal that addressing climate change is essential, so it can plan and invest. Low carbon infrastructure must be seen as a climate investment, not a climate cost. An entrepreneurial state should provide leadership and frameworks for green investment in infrastructure and energy generation.

The ability to breathe clean air is an important human freedom. Lung damage from air pollution occurs from the first few weeks of life through to old age. ${ }^{13}$ Tobacco-free and clean air policies are important to ensure that children's earlylife environment is conducive to optimum healthy lung growth, as is poverty reduction. After hypertension and smoking, air pollution is now the third leading contributor to death worldwide. ${ }^{14}{ }^{15}$ Reducing production of soot, methane and nitrogen oxides which promote the greenhouse effect will have a beneficial effect on climate change, and will also bring rapid health benefits to people locally. ${ }^{16}$ The president should promote a movement away from burning fossil fuels, coal in particular, and address methane production from fossil fuel extraction and agriculture.

Investment in public transport is needed to reduce traffic, together with the creation of infrastructure to promote walking and cycling. The associated increase in physical activity levels improves health and fitness, while simultaneously reducing harmful emissions and road traffic accidents. ${ }^{17}$ Similarly, energy-efficient housing stock can reduce energy consumption, while also mitigating the effects on respiratory health of rapid changes in weather. Improving access to urban green spaces encourages physical activity and improves air quality. Virtuous circles.

Margaret Thatcher said to the United Nations in 1989, 'The environmental challenge that confronts the whole world demands an equivalent response from the whole world. Every country will be affected and no one can opt out'. There is a practical and moral imperative to take action now to reduce current and future impacts of climate change. These actions have also the potential to improve health and prosperity directly. Responding to the threat of climate change will require innovation and global leadership. Action now is crucial if we are to protect the health of our people now and in future generations.

Acting on climate change is one way in which President Trump can make good on his promises to improve the well-being of Americans, increase America's energy independence and act with fiscal prudence. Investing in green infrastructure creates jobs. It reduces healthcare costs$1 / 4-1 / 3$ of the costs of decarbonising come straight back as health economic gains. ${ }^{4}$ If Trump wants America to lead, 
Table 1 Climate change to do list for a new president

\begin{tabular}{|c|c|}
\hline Action & Benefit \\
\hline Acknowledge scale of the problem & $\begin{array}{l}\text { Give business a clear message that low carbon is a stable } \\
\text { opportunity for investment } \\
\text { Support international efforts to reach agreement }\end{array}$ \\
\hline $\begin{array}{l}\text { Use the instruments of government to drive } \\
\text { investment and create markets }\end{array}$ & $\begin{array}{l}\text { Create jobs } \\
\text { Drive innovation }\end{array}$ \\
\hline Move to clean energy & $\begin{array}{l}\text { Reduce } \mathrm{CO}_{2} \text { emissions } \\
\text { Promote new technologies }\end{array}$ \\
\hline Accelerate move away from use of HFCs & $\begin{array}{l}\text { These are powerful greenhouse gases } \\
\text { Alternative solutions require innovation }\end{array}$ \\
\hline Prioritise active transport and public transport & $\begin{array}{l}\text { Reduce } \mathrm{CO}_{2} \text { emissions } \\
\text { Improve air quality } \\
\text { Improve health and fitness }\end{array}$ \\
\hline
\end{tabular}

then he needs to be at the front of the international climate change pack, not at the back (table 1). No one else will be quitting the race onwards to the betterment of their peoples.

Twitter Follow Nicholas S Hopkinson @COPDdoc; Nicholas Hart @NickHartThorax; Gisli Jenkins @IPFdoc; Naftali Kaminski @KaminskiMed; Alan Smyth @AlanRSmyth; Alex Wilkinson @DrAlexWilkinson.

Contributors NSH and AW produced the first draft. All authors contributed to and approved the final version.

Competing interests None declared.

Provenance and peer review Commissioned; internally peer reviewed.

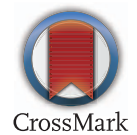

To cite Hopkinson NS, Hart N, Jenkins G, et al. Thorax 2017;72:295-296.
Published Online First 19 January 2017

Thorax 2017;72:295-296

\section{REFERENCES}

1 Woodcock A. The president speaks: prevention is best: lessons from protecting the ozone layer. Thorax 2012;67:1028-31.

2 Ross T, Meyer H. Trump Craves Reagan-Thatcher 'Special Relationship' With May. Bloomberg News, 10 Nov 2016. https://www.bloomberg.com/news/ articles/2016-11-10/may-trump-seek-to-revivereagan-thatcher-special-relationship (accessed 2021/ 2012/2016).

3 Velders GJM, Andersen SO, Daniel JS, et al. The importance of the Montreal Protocol in protecting climate. Proc Natl Acad Sci USA 2007;104:4814-19.

4 Watts N, Adger WN, Agnolucci P, et al. Health and climate change: policy responses to protect public health. Lancet 2015;386:1861-914.

5 Ayres JG, Forsberg B, Annesi-Maesano I, et al. Climate change and respiratory disease: European Respiratory Society position statement. Eur Respir J 2009;34:295-302. doi:10.1136/thoraxjnl-2017-209978
6 D'Amato G, Cecchi L, D'Amato M, et al. Climate change and respiratory diseases. Eur Respir Rev 2014;23:161-9.

7 D'Amato G, Bergmann KC, Cecchi L, et al. Climate change and air pollution: Effects on pollen allergy and other allergic respiratory diseases. Allergo J Int 2014;23:17-23.

8 Gerardi DA, Kellerman RA. Climate change and respiratory health. J Occup Environ Med 2014;56 (Suppl 10):S49-54.

9 Stafoggia M, Forastiere F, Agostini D, et al. Factors affecting in-hospital heat-related mortality: a multicity case-crossover analysis. J Epidemiol Community Health 2008;62:209-15.

10 Barnett J, Adger WN. Climate change, human security and violent conflict. Polit Geogr 2007;26:639-55.

11 Stern N. Economic development, climate and values: making policy. Proc Bio/ Sci 2015;282:20150820.

12 Stern NH. The economics of climate change: the stern review. Cambridge University Press, 2007.

13 Royal College of Physicians. Every breath we take: the lifelong impact of air pollution. London: Royal College of Physicians, 23 Feb 2016. https://www. rcplondon.ac.uk/projects/outputs/every-breath-wetake-lifelong-impact-air-pollution

14 Lim SS, Vos T, Flaxman AD, et al. A comparative risk assessment of burden of disease and injury attributable to 67 risk factors and risk factor clusters in 21 regions, 1990-2010: a systematic analysis for the Global Burden of Disease Study 2010. Lancet 2012;380:2224-60.

15 Lozano R, Naghavi M, Foreman K, et al. Global and regional mortality from 235 causes of death for 20 age groups in 1990 and 2010: a systematic analysis for the Global Burden of Disease Study 2010. Lancet 2012;380:2095-128.

16 Scovronick N. Reducing global health risks through mitigation of short-lived climate pollutants - scoping report for policymakers. WHO 2015. http://www. who.int/phe/publications/climate-reducinghealth-risks/en/

17 Sustainable Development Unit. Sustainable Development Management Plan (SDMP) Guidance for Health and Social Care Organisations. 2014. http://www.sduhealth.org.uk/delivery/plan.aspx 